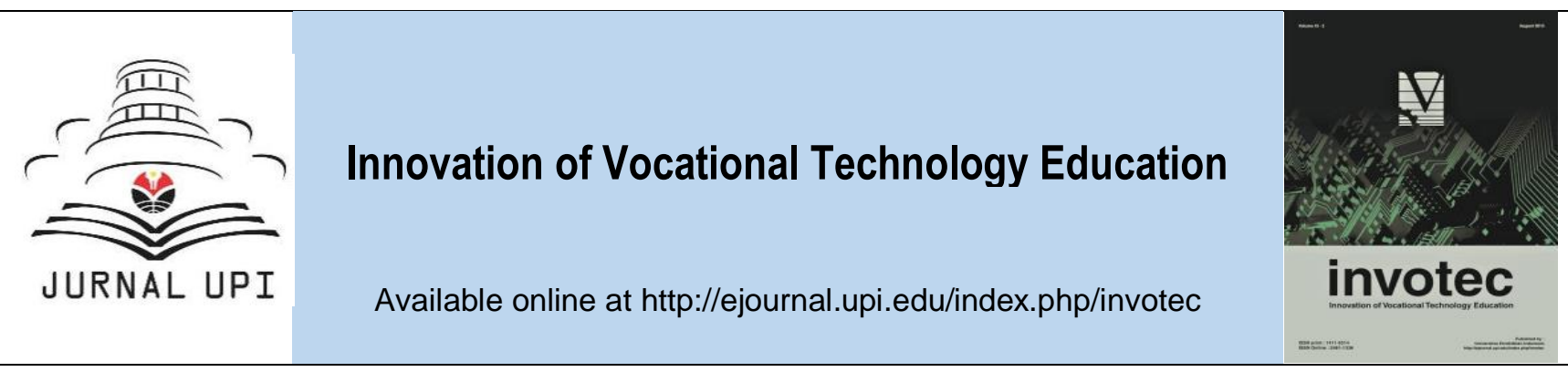

\title{
Employee Performance Assessment System Design Based on Competence
}

Syamsul. H. Senen, Sumiyati, Masharyono

Universitas Pendidikan Indonesia, Indonesia

\section{ARTICLE INFO}

A B S T R A T

\section{Article history:}

Received 22 March 2017

Received in revised form 17 April

2017

Accepted 28 April 2017

Available online 31 August 2017

Keywords:

employee performance

assessment,

evaluation system based on

competency

Corresponding author:

syamsulhadisenen@upi.edu

\begin{abstract}
Employees are one of the most important components owned by the organization in achieving the purpose. Success or failure an organization in exercised their activities related to the capacity of employees (competence) works in the organization. Therefore need to may system does performance evaluation of can give picture of the performance of employees. This research method is divided into five phases as preparation phase, the data collection phase, phase data processing, phase analysis, stage design system, system testing is limited. The results of this study to design employee performance evaluation system based on competency by name spkp-sms.org
\end{abstract}

\section{Introduction}

Employees are one of the most important components of which are owned by the company in its efforts to maintain viability, develop, ability to compete and make a profit (Senen, Sumiyati, Masharyono, 2013). No one company can survive if the company does not have employees who can work well and maximal. Success or failure of a company in carrying out its activities cannot be separated from the capacity of employees (workers) who do the work in the company (Ritonga, 2013).

The development of research performance measurement system is relatively developed adult with wide range of applications both profit and non-profit organizations (Neely, 1999, Gomes et al., 2004). Academics and practitioners believe that today, just pay attention to the financial aspect is not sufficiently representative describes the overall company performance (Kaplan \& Norton, 1996, Ghalayini et al., 1997, Neely \& Adams., 2000a). Any changes in a dynamic environment with increasingly intense competition conditions required not only financial aspects but also non-financial aspects. Hence the need for integrative performance measurement system (financial and nonfinancial aspects) is a must for companies (Vanany \&Tanukhidah, 2004).

The importance of performance measurement is not only necessary and carried out in the business world but also in the world of education. Thus the importance of performance measurement in the management of universities or education, the Directorate General of Higher Education put in new management format that aims to improve the quality of education on an ongoing basis. Improving 
the quality of education on an ongoing basis is done by entering the assessment, accreditation and institutional self-evaluation conducted on universities, both public and private (Soehendro, 1996; I Suartika, et. al. 2007). Therefore, the need for employee performance evaluation system based on competence.

The system is a collection/group of subsystems/parts/components whatsoever either physical or non-physical are interconnected with each other and work together in harmony to achieve a certain goal (Susanto, 2008). Performance is indeed often regarded as simply the outcomes achieved: a record of a person's accomplishments (Amstrong, 2010). As for the aspects of performance criteria is quantity of work, quality of work, job knowledge, reactiveness, cooperation, dependability, initiative, and personal qualities (Gomes, 2010). Task performance and contextual performance rating has consistently shown that employees who stay with the organization have higher performance rating than those who leave the organization, meaning that there is a negative correlation between the performance and the intention to leave the organization (Musriha, 2013). Competencies are descriptions of the characteristics and qualities that a person a needs to process to perform a job successfully. Spencer and Signe (1993) Competence is underlying characteristics of an individual that causally related to criterion referenced effective and/ or superior performance in a job or (Pynes, 2009). The criteria for competence Spencer is organizational commitment, desire of achievement, serving, research agreement, proactive, lead, and discipline.

\section{Method}

This research uses case study method. This research method is divided into five phases as follows: preparation phase; a stage to identify or bring problems, namely how to design the proposed competency-based performance appraisal system; the data collection phase by interview, documentation study organization; phase data processing consisting of several processes, namely the preparation of behavioral competencies or personal abilities; phase analysis furthermore, analyzed the output of each step of the design performance measurements analyzed; stage design system; and system testing is limited.

\section{Result and Discussion}

Employee assessment system is a web-based application that can assist organizations in assessing the performance of the employee. Activity diagrams is something that represents a wide range of flow activity in the system that is being designed, how each flow starts, decision that might occur, and how they ended. Activities employee performance appraisal system design (Figure 1) in this study are:

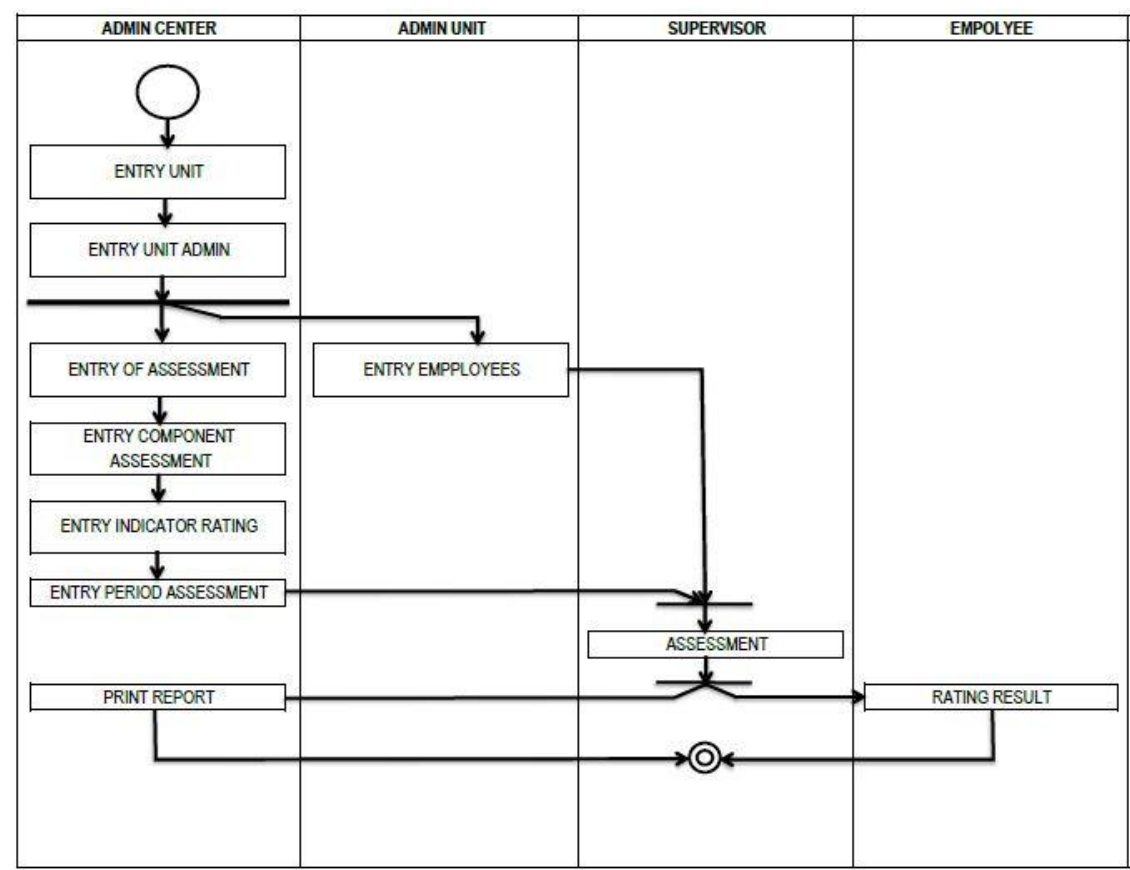

Figure 1. Activity diagram 
The login page is the main page when users access applications Employee Assessment System. Employee Performance appraisal system (spkp-sms.org/auth/login).

\section{Conclusion}

The design of a competency-based performance appraisal system in this study is called spkpsms.org/auth/login

\section{References}

Armstrong, M. 2010. Armstrong's essential human resource management practice: A guide to people management. Kogan Page Publishers.

Ghalayini, A.M., J.S. Noble \& T.J. Crowe. 1997. An integrated dynamic performance measurement system for improving manufacturing competitiveness. International Journal of Production Economics 48(3): 207-25.

Gomes, F.C., M.M. Yasin \& L.V. João. 2004. A literature Review of Manufacturing Performance Measures and Measurement in an Organizational Context: A Framework and Direction for Future Research. Journal of Manufacturing Technology Management 15(6): 511-530.

Kaplan, R.S. \& D.P. Norton. 1996. Translating Strategic into Action-The Balanced Scorecard. Massachussets: Harvard Business School Press.

Musriha. 2013. Influence of Teamwork, Environment on Job Satisfaction and Job Performance of the Cigarette Rollers at Clove Cigarette Factories in East Java, Indonesia Spencer. In Lyle M. \& Signe M.S. 1993. Competence at Work: Model for Superior Performance, John Wiley and Sons Inc. Developing Country Studies ISSN 2224-607X (Paper), 2225-0565 (Online) 3(2), 2013.

Neely, A.D. 1999. The performance revolution: why now and what next?. International Journal of Operations \& Production Management 19(2): 205-8.

Neely, A.D. \& Adams, C.A. 2000a. Perspectives on Performances: The Performance Prism, Centre for Business Performance. Cranfield School of Management, UK.

Pynes, E.J. 2009. Human Resources Management for Public and Nonprofit Organizations A Strategic Approach. Jossey-Bass A Wiley Print.

Ritonga, S.K. 2013 Information System Employee Performance Appraisal Method Using Technique for Others Reference by Similarity to Ideal solution (topsis). Pelita Informatika Budi Darma $\operatorname{IV}(2)$.

Senen, H.S., Sumiyati \& Masharyono. 2013. Honorary Employee Job Performance Analysis Administration Competency and Job Characteristics in Supporting Indonesia. University of Education Leading and Achieving Outstanding.

Soehendro, B. 1996. Framework for Long-Term Higher Education Development 1996-2005. Project Development and Support Staff College (PPS2PT). Jakarta.

Spencer, L.M. \& Signe M.S. 1993. Competence at Work: Model for Superior Performance. John Wiley and Sons Inc.

Suartika, I.M., Suwignjo, P. \& Syairuddin, B. 2007. Design and Implementation System Performance Measurement Method of Integrated Performance Measurement Systems (Case Study: majoring in mechanical engineering university mataram). Jurnal Teknik Industri 9(2): 131143.

Susanto, A. 2008. Accounting information system. Structural Risk Control Development. Bandung: Lingga Jaya.

Vanany, I. \& Tanukhidah, D. 2004. Design and Implementation of Performance Measurement System Performance with PRISM Method. Jurnal Teknik Industri 6(2): 148-155. 